\title{
From Insecurity to Secondary Migration: "Bounded Mobilities" of Syrian and Eritrean Refugees in Europe
}

\author{
Irene Tuzi ${ }^{1}$
}

\section{Abstract}

This paper seeks to analyse Syrian and Eritrean refugees' mobility experience across European borders, in a framework of mobility and insecurity. Drawing on the conflict model of migration, the paper focuses on the effects of migration and asylum policies when these are not in line with refugees' needs and aspirations. We argue that when the asylum system does not meet with those expectations, insecurity brings into play secondary movements, which occur in a framework of irregularity. The considerations behind this article are motivated by the empirical evidence that both Syrian and Eritrean refugees undertake irregular secondary migration, whilst being within a protection system that most of the times satisfies their asylum claims. This paper is the result of a qualitative research conducted in 2017 through observation, in-depth interviews with Syrian and Eritrean refugees, and consultations with experts and practitioners in Italy, Greece, Germany and Lebanon.

Keywords: secondary movements; Syrian refugees; Eritrean refugees; forced migration; insecurity.

\section{Introduction}

As migration becomes increasingly recognised as a component of contemporary European societies, EU policies become increasingly complex and challenging for global movements (Bougleux 2016; Czaika and de Haas 2014; Glick-Schiller and Salazar 2013; Bærenholdt 2013; Bigo 2006; Ambrosini 2005; Cunningham and Heyman 2004). Migrants and refugees are highly affected by the way Europe deals with their movements and their hospitality (Cresswell, 2006). However, European policies do not look fully at these people's needs after their arrival to Europe, for they are somehow perceived as monolithic entities in their motives, abilities or expectations towards their life in Europe. The aim of this article is to understand why forced migrants, who have been granted formal resettlement, undertake secondary migration movements outside the legal European framework. Little is understood concerning why movers seek new destinations after they have arrived in Europe. This article focuses on two nationalities of forced migrants - Syrians and Eritreans. It looks at their experience of mobility across borders following the resettlement provided by Europe. The case studies accounted for in this paper are two: the resettlement of Syrian refugees in Italy and the relocation of Eritrean refugees from Italy. The considerations behind this article are driven and motivated by the empirical evidence that both Syrian and Eritrean refugees undertake irregular secondary migration movements across European countries - whilst being within a protection system that most of the times satisfies their asylum claims. What are the reasons behind

\footnotetext{
${ }^{1}$ Irene Tuzi, PhD candidate in Social Sciences at Sapienza University of Rome, Italy, and Humboldt University of Berlin, Germany. E-mail: irene.tuzi@uniroma1.it; irene.tuzi@hu-berlin.de.
} 


\section{From Insecurity to Secondary Migration}

those movements and the factors affecting the decision to move forward in a framework of 'irregularity'??

\section{Forced Migration Trajectories of Syrian and Eritrean Refugees}

Both Eritreans and Syrians migrate to Europe seeking asylum. They are two different refugee communities in terms of the path, type and causes of migration. Yet, when forcibly migrating to Europe, they have a similarity: a nationality with an EU-wide average asylum recognition rate of $75 \%$ or higher. This means that they have favoured access to asylum in many European countries as well as the possibility of moving regularly across borders through a temporary relocation scheme for asylum seekers or through the resettlement programme.

The main reason reported behind Syrian migration is the on-going Syrian conflict, which has resulted in nearly 500,000 deaths, two million people injured, and the forced displacement of half of the population of Syria - twelve million people displaced inside and outside of the national borders. ${ }^{3}$ Syrian refugees flee mostly to the neighbouring countries of Lebanon, Jordan and Turkey and tend to remain there waiting for favourable conditions to return. ${ }^{4}$ Only about one million Syrian refugees have sought asylum in Europe, with Germany, together with Sweden, being the top EU receiving countries (UN Refugee Agency, 2017). ${ }^{5}$ From their first country of displacement, after having registered as asylum seekers under the UNHCR, Syrians refugees are eligible to be resettled in a EU Member State. On the other hand, when crossing borders spontaneously, they arrive in Greece from Turkey or in Italy from Libya. In this case, Syrians are also offered the possibility to be transferred to another member state through the relocation programme.

As for Eritreans, their movements are mostly reported as induced by human rights violations produced by twenty-five years of oppressive rule by Isaias Afwerki. Eritrea is considered one of the most oppressive governments in the world owing to its centralised regime, highly corrupted justice system, lack of freedom of speech, and indefinite compulsory military draft, which has been described by the UN Human Right Agency (OHCHR) as "enslavement". ${ }^{6}$ Eritreans mostly undertake spontaneous migration to Europe. They land on the Italian southern costs of Sicily after having crossed the bordering countries of Ethiopia and/or Sudan, having spent an indefinite amount of time in Libya, and having crossed the harshest of the borders - the Mediterranean Sea. Eritreans are also offered the opportunity to be resettled, but they mostly move spontaneously to Europe. Since 2015, they have been eligible for relocation, thus they can move through member states regularly. Despite the historical ties between Italy and the Horn of Africa, most Eritreans are willing to settle in Northern and Central European countries, especially Germany and Sweden.

\footnotetext{
${ }^{2}$ Irregularity is considered here as acting outside the legal framework, namely without the prior consent of the country of first arrival or without sufficient documentation normally required for travel purposes. See EPRS Secondary movements of asylum-seekers in the EU asylum system: http://www.europarl.europa.eu/RegData/etudes/BRIE/2017/608728/EPRS_BRI(2017)608728_EN.pdf. Retrieved on April 5, 2018.

${ }^{3}$ See Syrian Refugees. A Snapshot of the Crisis: http://syrianrefugees.eu.

${ }^{4}$ Recent studies (Yahya et al., 2018) have asserted that, at the present time, Syrian refugees are not ensured with the conditions for return. This means that unless refugees are offered the opportunity to resettle in a third country, they remain in displacement in firstasylum countries, where they live in limbo.

${ }^{5}$ See the UNHCR Population Statistics Database for updated data: http://popstats.unhcr.org/en/overview. Retrieved on December $17,2017$.

${ }^{6}$ See the UN Human Rights Office of the High Commissioner (OHCHR, 2016) Detailed findings of the commission of inquiry on human rights in Eritrea: http://www.ohchr.org/Documents/HRBodies/HRCouncil/CoIEritrea/A_HRC_32_CRP.1_read-only.pdf
} 


\section{Informal Secondary Movements}

Secondary migration is the phenomenon whereby migrants and refugees ${ }^{7}$ move from the country in which they have first arrived, or resettled, to seek permanent resettlement elsewhere. In Europe, such movements are restricted by the Dublin Regulation, a legal tool that defines the member state of first arrival as the responsible entity for examining the asylum application lodged by a third country national. ${ }^{8}$ Nevertheless, according to Denaro and Vassallo Paleologo (in Petroff et al. 2018), secondary migration movements are aimed at overcoming the restrictions imposed by the Dublin Regulation. In particular, throughout the so-called "refugee crisis", these movements have put a strain on the system; they have deeply challenged its functionality and altered not only refugees' position in the system, but also that of authorities of the first EU arrival countries (Ibid. 2018: 52). According to Radjenovic (2017) there are different factors influencing secondary movements, "these include the time and reasons for departure; entry, exit and transit requirements in the countries concerned; personal circumstances; material resources; historical or cultural ties to specific countries; family or other social networks; and rumours and chance" (Radjenovic 2017: 2). Such movements are often undertaken in an irregular manner, which means without having obtained an entry visa from the country of destination. ${ }^{9}$ Brekke and Brochmann (2015) argue that refugees are motived to move onward mostly for economic reasons, such as access to labour markets and working opportunities, differences among living standards and wages conditions. Nonetheless, Poppy and Mayblin (2016) have evidenced that there are other factors influencing asylum destination choice, these being: existing social networks, familiarity with culture and language as well as past colonial ties. Also, the reputation of a destination country and the chances that refugees' skills will be valued play a role.

In the African migration context, Toma and Castagnone (2002), among others, have evidenced an increasing fragmentation of the migrants' journey (see also Castagnone 2011; and Schapendonk 2010). The authors observed that in response to the border control policies of European States, "step-by-step migration" (Bredeloup and Pliez, 2005) is progressively developing as an emerging migration strategy among Senegalese migrants. A different perspective is given by Lindley and Van Hear (2007), who have evidenced education as the second area, after economic reasons, where there have been push and pull factors encouraging Somali migrants to move onwards from mainland Europe to the UK. In this sense, an interesting perspective is given by the life course approach, "developed in the social sciences as a means of examining the evolution of individuals' life trajectories over time and across social processes" (Toma and Castagnone 2002: 67). Since the lives of individuals are always in transition and because there is interdependence of trajectories in the different domains of their lives (Dykstra and Van Wissen, 1999), people's decision on the country of residence can vary according to their stage in life.

Concerning the two focal refugee communities of this study, recent literature (Schuster 2006; Brekke and Brochmann 2014; Costantini 2015, Belloni 2016) has observed high rates of secondary migration movements among Eritreans - up to $80 \%$ in certain areas. When attempting to leave Italy,

\footnotetext{
${ }^{7}$ In a framework of mixed flows, in this paper, we intend for "refugee " not only the legal category of people having obtained the asylum status, humanitarian or political, but also asylum seekers and those who, for different reasons are compelled to leave their country of origin and seek protection elsewhere. Nonetheless, as explained later, the two communities tracked for this research are granted humanitarian asylum in most European countries.

${ }^{8}$ Regulation (EU) No 604/2013 of the European Parliament and of the Council of 26 June 2013. See here for the full text: https://eur-lex.europa.eu/legal-content/EN/TXT/HTML/?uri=CELEX:32013R0604\&from=en.

${ }^{9}$ See: UNHCR 40th Executive Committee, Problem of Refugees and Asylum-Seekers Who Move in an Irregular Manner from a Country in Which They Had Already Found Protection: https://www.unhcr.org/excom/exconc/3ae68c4380/problem-refugees-asylumseekers-move-irregular-manner-country-already-found.html October 1989.
} 


\section{From Insecurity to Secondary Migration}

they often remain stuck in transit in Ventimiglia, a city in the North of Italy, $40 \mathrm{~km}$ from Nice. Crossing the French border became very harsh during the last few years, because the government introduced strict security measures and "migrant-hunting" actions on the trains between Italy and France (Palidda and Martini, 2018). Italy represents a "transit country" also for Syrian refugees, whilst their secondary migration movements are somewhat less visible - and not accounted for yet. As noted by Denaro (2016), during the first phase of the "refugee crisis", Syrian refugees arriving spontaneously by sea engaged in high levels of agency and resistance by avoiding the provision of fingerprints. This entailed an "unbounded mobility" and the possibility of having a free choice in terms of the country of asylum.

Whilst tackling the identification of important factors driving migrants and refugees' secondary movements, researchers have not given sufficient attention to the personal aspirations of individuals. This study is aimed at going further than the macro-level reasons that might drive secondary movements, and looking at the micro-level motivations and aspirations of individual as active agents forging their own future.

\section{Conceptualising Refugees' Mobility}

Several theoretical tools have been used by scholars to conceptualise human mobility (see Massey et al., 1993 for an overview), but while they can explain why migration may occur, they lack in eliciting the individual factors encouraging people to move onward, the personal consequences of migration, and the individual challenges of integration. A framework that can more fully capture the complexity of secondary migration movements is perhaps the merging of two concepts: insecurity and aspirations. For this study we found particularly useful the conceptualisation of human mobility undertaken by Sirkeci and Cohen (2016). They argue that human mobility is triggered by conflicts. Their model defines conflict not only as a key driver of human mobility. It also maintains that it is the perception of insecurity entailed by conflicts that drive mobility. According to the authors, human mobility occurs under a perception of insecurity, "when insecurity is manageable, one does not encounter increasing migration", but when it is unbearable and "individuals, families or communities are equipped with the means enabling movement", people flee or keep moving across borders (Sirkeci and Cohen, 2016; Cohen and Sirkeci, 2011 and 2016).

In this article, we apply the concept of insecurity to secondary movements and we argue that this not only drives primary migration but also, keeps triggering movements even after the resettlement process has started or concluded. Ultimately, we argue that insecurity occurs when at a certain stage of people's lives, their aspirations are not satisfied.

\section{The insecurity-mobility model}

The model that we use to describe the mobility of Syrians and Eritrean refugees in Europe is based on the key assumption that mobility is not only induced by conflict but more specifically by insecurity. We assume that the existing European "mobility regime" affects Eritrean and Syrian refugees in their movements because it is set out as a framework of "bounded mobility" (Gutekunst et al. 2016) ${ }^{10}$, whereby refugees are granted mobility and imposed immobility at the same time. Secondary movements occur within this framework of bounded mobility. As we can see from Figure 1 , in the first phase after initial forced movements, refugees are under the asylum system, their

\footnotetext{
${ }^{10}$ Gutekunst et al. (2016) refer to the dichotomy between mobility and immobility as "bounded mobility" and they suggest that rather than looking at them separately we should analytically look at them as interconnected states. They maintain that the plural of the term "mobility" expresses its diversity and its many forms.
} 
initial basic needs are satisfied and basic protection is guaranteed. In this case, security is high and refugees are not willing to move forward. They are also unable to move further because the protection offered through international law is applicable only under the jurisdiction of the country of asylum. In other words, their mobility is bounded. In the second phase, after initial forced movements, refugees have overcome the conflict and driving reasons of first mobility. Now, the balance between losses and gains changes. The satisfaction of basic needs has been accomplished, but other challenges are expected, with future opportunities and educational development being now the main concerns. For this reason, when the asylum system does not meet with those aspirations, insecurity brings into play secondary movements, which, in turn, are bounded by border policies and thus, have to occur in a framework of irregularity.

Figure 1: The insecurity-mobility model

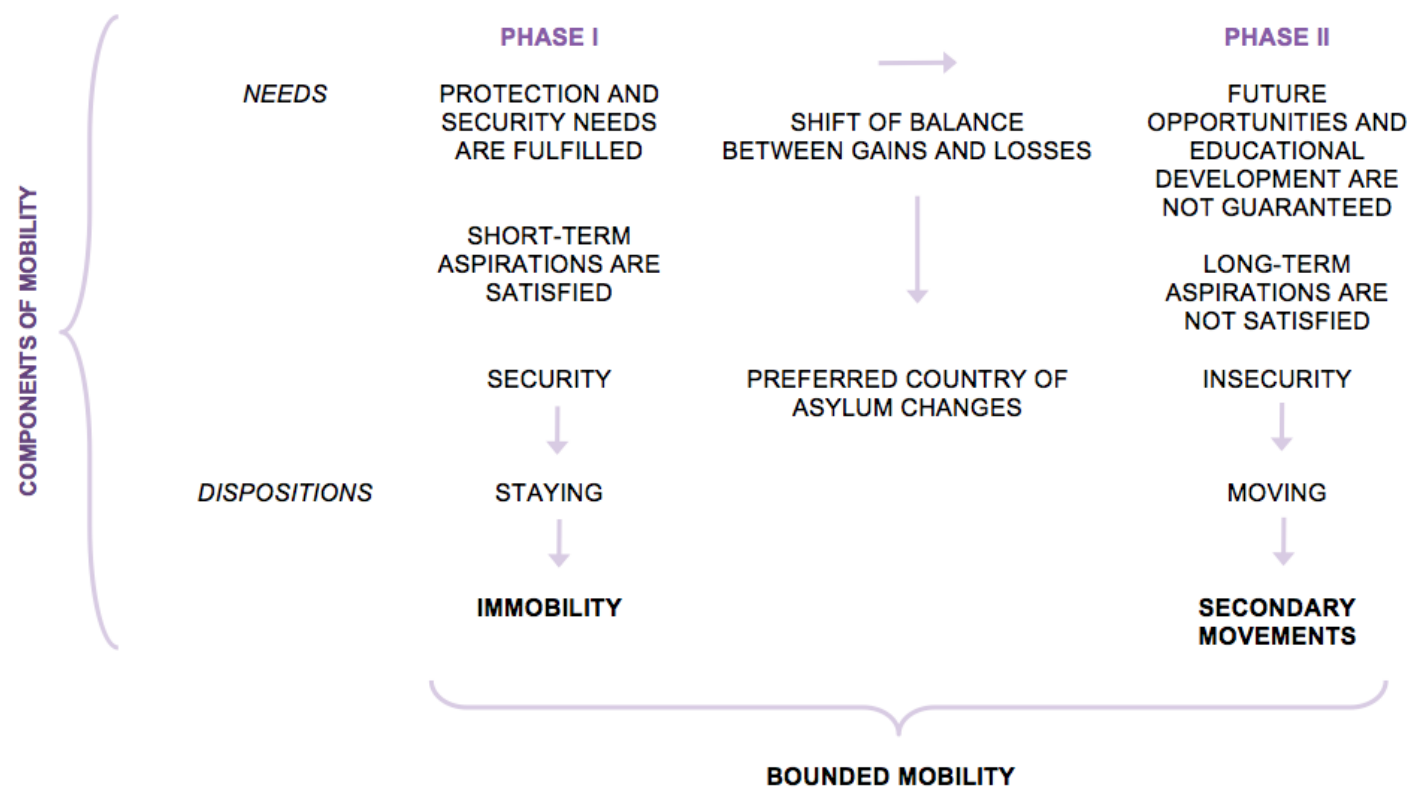

\section{Bounded Mobilities of Syrian and Eritrean Refugees in Europe}

This qualitative study was carried out by the author in 2017 through observation at refugee reception centres in Italy. Moreover, in-depth interviews with Syrian and Eritrean refugees within the programmes of relocation, resettlement, and humanitarian corridors were undertaken along with consultations with experts, practitioners, and UN officers in Italy, Greece, Germany and Lebanon.

The resettlement of Syrian refugees in Italy

The literature refers to the resettlement of Syrian refugees as the largest commitment in recent history (Batchelor and O'Shea, 2017), which has been facilitated by the Syria Core Group (SCG) formed in 2013. Nonetheless, access to resettlement has not been equally promoted (Esses and Gaucher, 2017). For example, when assessment criteria only take into consideration the vulnerability of refugees, it has been noticed that certain categories of refugees remain left aside 


\section{From Insecurity to Secondary Migration}

(Turner, 2017). ${ }^{11}$ The Italian resettlement programme, based on a system of bilateral negotiation, has mostly involved transferring Syrians from Lebanon and Turkey. ${ }^{12}$ In most cases, Syrian refugees do not consider Italy as a country favourable for resettlement. Misconceptions about the country have appeared among Syrian refugees in the resettlement process. ${ }^{13}$ The main problem has emerged to be the gap between refugees' aspirations and the ability of Italy to deal with their problems - to the extent that, often, Syrian refugees tell social workers that they wish they had never left first asylum countries ${ }^{14}$. In particular, educated young Syrians departed their country with high expectations in relation to educational and job opportunities, but what they faced, in reality, was not what they expected. Tufiq, one participant, arrived in Italy in 2015, after having lived in Lebanon for two years. He could not go back to Syria, because of the military conscription law ${ }^{15}$ and lived without regular residency in Lebanon. He arrived in Italy through resettlement with great expectations, wanting to continue his studies, which he had interrupted years earlier in Syria.

I left Syria to escape from the forced military conscription imposed by the regime. I didn't want to go to war and die, so I went to Lebanon and then I was lucky enough to be resettled here [in Italy]. But life is hard. I was a university student in Syria. I had expectations of a brilliant future before the war. Here I have to work all the time, day and night. My aspiration when I came here was to keep studying, but the years are passing by and it is never the right time, or I don't have the time, motivation, or money. I didn't expect my life to be like this. ${ }^{16}$

The lack of work possibilities in rural areas of Italy is the concern of many families. In particular, those coming from urban areas in Syria, who have also lived in such areas in the countries of first asylum, lamented about adaptation issues. Anas is a father and a husband who was working as an engineer in Syria. Because he cannot find a satisfactory job in Italy he is experiencing discontent and depression. At interview he expressed the desire to leave the country.

Our first need is to live in a safe environment of course, but also in dignity. We want a decent education for our children and a decent life for our family [...]. I was an engineer in Syria and I came to Europe with the hope of keep doing my job and supporting my family, of course. [...] I don't want to stay in Italy, because there are no job opportunities here for me as an engineer. ${ }^{17}$

The process of resettlement does not take into account the social and geographical composition of the country of destination. ${ }^{18}$ Most Syrian refugees who have been transferred to Italy had a

\footnotetext{
11 Turner has mentioned the case of unaccompanied heterosexual Syrian men, who, in 2015 were deliberately excluded from resettlement to Canada. In addition, a consultation with IOM officers in Italy confirmed that sometimes only a specific category of refugee is selected for resettlement - such as in the case of Kurdish Syrians resettled from Turkey.

${ }^{12}$ In the period between 2013 and 2017, almost 100,000 Syrian refugees were resettled, of whom 1,200 were sent to Italy.

${ }^{13}$ Interview with an IOM officer in Italy (July 2017).

${ }^{14}$ According to the UNHCR, the "country of first asylum" is that which allows refugees to enter its territory for purposes of providing asylum temporarily, pending eventual repatriation or resettlement. Usually, such countries receive the support of the UNHCR to provide basic assistance to refugees. See: European Commission Migration and Home Affairs' Asylum Procedures Directive (ADP):https://ec.europa.eu/home-affairs/what-we-do/policies/asylum/common-procedures_en. Retrieved September 5, 2017.

${ }^{15}$ Syrian conscription law requires mandatory military service for Syrian men aged between 18 and 42 . However, those who have already completed compulsory military duty can still be recalled for active duty in the event of a war. Many Syrians aged between 18 and 42 fled the country to escape the compulsory extra conscription imposed by the Syrian regime.

${ }^{16}$ Interview with Tufiq, a Syrian man living in a reception centre in Rome, Italy (September 2017).

${ }^{17}$ Interview with Anas, a Syrian man living in a reception centre in Rome, Italy (September 2017).

${ }^{18}$ Fernandez-Huertas et al. (2014) and Moraga and Rapoport (2016) developed a multilateral system of Tradable Immigration Quotas (TIQs), which includes a mechanism to match immigrants to destination countries.
} 
relatively wealthy life before the war. For them, the transfer to small, isolated villages in southern Italy is a rather negative experience. According to the IOM,${ }^{19}$ those who accept Italy as a destination country were either already living in disadvantaged conditions, or came from rural areas. Syrian refugees interviewed for this research have also confirmed the abovementioned shortcomings.

Resettled refugees are not given full information about the whole process of resettlement and what to expect after it. Ahmad, one participant, argued that resettlement did not give him the tools to deal with his new life and that there are discrepancies between the new reality and the future he expected when he joined the programme.

I somehow hoped that with resettlement I would have had my old life back. I wouldn't expect it to be so different here. I don't know how I could ever earn enough money to support my family, to send my children to university, to buy a house or something like that. There is nothing that I can do. Now I know that what I had in Syria will never come back. [...] I would like to travel somewhere else, yes, but I don't know where and how. ${ }^{20}$

The role of the informal transfer of information among refugees has also emerged as an important element capable of influencing their decisions. Those who have already been transferred use Facebook and WhatsApp to interact with those who are about to leave; sometimes affecting the latter's decision to leave. As referred to by IOM Italy, these kinds of interactions have a stronger role in determining refugees' decisions than the formal information given by organisations.

Our colleagues in Lebanon or Turkey refer to us that during the informative sessions held as preparation for departure beneficiaries show messages that contain wrong information - for example, rumours about the fact that in the hosting country women will no longer be able to wear a veil. This information exchange is very powerful and often the information we give is not able to have the same impact. Whatever is said by a refugee, who has experienced personally the resettlement to another country, will always have a greater effect than what an organisation says. ${ }^{21}$

The décalage between aspirations and reality creates insecurity towards the future. All the participants in this study expressed the desire to move onward. For most of them, this was more an idea than a plan, whilst others had in mind a project to reach out friends or relatives in another country. The social network variable was often present, but it came into play after the preference regarding the country of asylum had already changed. Whilst there are no official data regarding secondary migration movements of Syrian refugees in Europe, empirical evidence shows that within the resettlement system, the tendency of moving from one country to another is becoming rather widespread among those resettled in Italy.

The relocation of Eritrean refugees from Italy

The programme of relocation entails the distribution among member states of persons in clear need of international protection. The system provides for the transfer of people whose nationality has a protection rate that is recognised at least $75 \%$ of the times. ${ }^{22} \mathrm{After}$ having requested asylum in the first country of arrival in Europe (Italy or Greece), refugees are transferred to another member

\footnotetext{
${ }^{19}$ Interview with an IOM officer in Italy (July 2017).

${ }^{20}$ Interview with Ahmad, a Syrian man living in a reception centre in Rome, Italy (September 2017).

${ }^{21}$ Interview with an IOM officer in Italy (July 2017).

${ }^{22}$ Mostly Syrians, Eritreans, Central Africans, and Bahrainis.
} 


\section{From Insecurity to Secondary Migration}

state for the purpose of examining the application for international protection (Carlsen, 2017). ${ }^{23}$ Hence, the formal obligation of the first EU country of arrival in examining applicants' claims is now revised and temporarily reformed into a framework of sharing protection responsibility between EU member states, according to a system of quotas (Moraga and Rapoport 2017).

As for the Italian case, mostly Eritrean refugees benefit from the programme. They are single individuals moving independently from their families, who stay behind waiting to be later reunited with them. It is important to highlight that relocation involves refugees already on European territory, namely it does not provide protection against the journey across borders and all the challenges that this entails, including such as: the crossing of the Sahara desert, the indefinite sojourn in Libya, the extreme violations of human rights undergone, torture, violence and last but not least, the extremely risky crossing of the Mediterranean Sea. Matios, one Eritrean participant, started his interview by talking about the difficulties of the journey:

I went through Eritrea, Ethiopia, Sudan, Libya... and then, Italy. I knew that the journey would be very difficult, but I had no other choice, because there [in Eritrea] we die ... [...]. Staying in the country [Eritrea] is not an option. ${ }^{24}$

As in Matios' case, often the difficulties of the trip are not a deterrent for departure, because the perception of the risk compared to the life in the home country favours the journey. In addition, the experience of those who manage to reach Europe drives other people's choice to leave. When we asked Dawit, an Eritrean young man who was about to be relocated to Spain, if his experience had conditioned other people's journey, he said:

When I tell people at home that Spain is a democratic country, and that over there I

will be able to study, they express the desire to leave too. Yes, the information that I give pulls people out of the country. ${ }^{25}$

Since the decision on the country of relocation is not made by refugees, but by authorities, the assignment of one or another may cause discontentment, especially when refugees are assigned to a country where they are not particularly pleased to settle. This is the case of Goitom, an Eritrean man who arrived in Europe to obtain better opportunities for his family, after having spent his whole life without being able to support them properly.

I was in military service throughout my whole life, and with my pay I wasn't able to support my family. I could not even desert the service, so I decided to leave and help my family from outside. [...] Now I feel safe, but I will not be happy until my family joins me. First, I want my family to join, then my children to study. I'm not happy to go to Spain, they told me there are no job opportunities there, but I'm not afraid to move again, if I need to. ${ }^{26}$

When migrating to Europe, Eritreans imagine their life in terms of their social and educational development in the countries of Northern and Central Europe. Yet, similarly to the Syrian case, social networks are not the first variable affecting their decision to move, for this only comes into

\footnotetext{
${ }^{23}$ The relocation scheme, which was aimed at moving 160,000 refugees from Italy and Greece to other member states, came to an end in September 2017. At the time of writing, the processing of pending relocation cases is still ongoing. A new voluntary mechanism for relocating refugees is being discussed as part of an update to the Dublin Regulation.

${ }^{24}$ Interview with Matios, an Eritrean man living in a reception centre in Rome, Italy (September 2017).

${ }^{25}$ Interview with Dawit, an Eritrean man in a reception centre in Rome, Italy (September 2017).

${ }^{26}$ Interview with Goitom, an Eritrean man in a reception centre in Rome, Italy (September 2017).
} 
play when the decision to move onwards is made. Often, social networks are even less strong than informal information passed on by the community, as in the case of Abraham.

Before leaving Eritrea, I asked people which country allows family reunification and they told me the Netherlands. So, when I left Eritrea I wanted to go there to make sure my family could reach me. ${ }^{27}$

Beyond basic initial protection, Eritrean refugees need to secure their left-behind families a future. As confirmed by Yemane, interviewed in Rome, information received shapes the perceptions on a country of resettlement, and shifts aspirations accordingly.

Actually, I would like to go to Germany. I know that I can study there. For all my life I wanted study and now that I am in Europe, I want to realise my dream. I'm happy that I am leaving Italy, I lived here for a year and I wasted my time. You are stuck here in this camp [i.e. reception centre] waiting, without doing anything. ${ }^{28}$

According to the IOM, Eastern and Southern European countries like Portugal, Romania, Spain or Italy, are considered undesirable countries for relocation and resettlement. Not only are these countries rather unknown in the imagination of Eritreans they are also seen as those that do not adequately support their integration as well as their social and economic development.

\section{Conclusion}

When under forced migration, people take into account the balance between gains and losses, which changes over different phases of life. In the first place, wars and persecution tip the scales in favour of migration, because this is perceived as a gain compared to the current condition. Then, after having fulfilled the basic needs of safety and protection, the balance between gains and losses changes, and the country of asylum makes the difference in terms of long-term opportunities. In general, the empirical observation has suggested that when the transfer from a country of asylum to another is not likely to improve refugees' situation in the long term, insecurity prevails, thus entailing secondary movements. As we have noted, secondary migration is stimulated by people's aspiration for a better future and life opportunities, but it also intersects with other variables like social networks, and economic reasons.

This study has confirmed that the main challenge for governmental transfer programmes, like resettlement and relocation, is to deal with refugees as individuals, rather than numbers. The perception of refugees and migrants as monolithic entities, rather than individuals with aspirations, needs, and expectations, will hinder the creation of a more sustainable hospitality system, and keep fostering secondary movements in a framework of insecurity.

\section{References}

Ambrosini, M. (2005). Sociologia delle migrazioni. Bologna: Il Mulino.

Batchelor, C. and O'Shea, E. (2017). "The internationalisation of resettlement: Lessons from Syria and Bhutan”, Forced Migration Review, 54: 9-11.

Bærenholdt, J. O. (2013). "Governmobility: The powers of mobility", Borders and Mobilities, 8: 20-34. https://doi.org/10.1080/17450101.2012.747754

${ }^{27}$ Interview with Abraham, an Eritrean man in a reception centre in Rome, Italy (September 2017).

${ }^{28}$ Interview with Yemane, an Eritrean man in a reception centre in Rome, Italy (September 2017). 


\section{From Insecurity to Secondary Migration}

Belloni, M. (2016). "My uncle cannot say 'no' if I reach Libya: unpacking the social dynamics of border-crossing among Eritreans heading to Europe", Human Geography, 9 (2): 47-56.

Bigo, D. (2006). "Globalized (in)security: The field and the ban-opticon". In N. Sakei and J. Solomon (eds.) Traces 4: Translation, Biopolitics, Colonial Difference, Hong Kong: Hong Kong University Press.

Bougleux, E. (2016). "Im/mobilities in subjects and systems". In M. Gutekunst, A. Hackl, S. Leoncini, J. S. Schwarz, I. Götz (eds.) Bounded Mobilities: Ethnographic Perspectives on Social Hierarchies and Global Inequalities, Bielefeld: Transcript Verlag.

Bredeloup, S. $\quad$ and Pliez, O. (2005). "Migrations $\quad$ entre les deux rives du Sahara", Autrepart, 36: 3-20. https://doi.org/10.3917/autr.036.0003

Brekke, J. and Brochman, G. (2014). "Stuck in transit. Secondary migration of asylum seekers in Europe. National differences and the Dublin Regulation", Journal of Refugee Studies 28 (2): 145-162. https://doi.org/10.1093/jrs/feu028

Carlsen, J. (2017). "An alternative view on distribution keys for the possible relocation of refugees in the European Union", Social Indicators Research 130 (3): 1147-1163. https://doi.org/10.1007/s11205-016-1234-4

Castagnone, E. (2011). Building a Comprehensive Framework of African Mobility Patterns. The Case of Migration between Senegal and Europe. Department of Social And Political Studies, Graduate School in Social, Economic and Political Sciences. Retrieved on January 12, 2019 from: https://www.ined.fr/fichier/s rubrique/ 22087/phd.thesis.castagnone.np.fr.pdf

Cohen, J. and Sirkeci, I. (2011). Cultures of Migration. The Global Nature of Contemporary Mobility. Austin: University of Texas Press.

Cohen, J. and Sirkeci, I. (2016). "Migration and insecurity: Rethinking mobility in the neoliberal age". In J. G. Carrier (eds.) After the Crisis, Anthropological Thought, Neoliberalism and the Aftermath, New York: Routledge. https://doi.org/10.4324/9781315657417-8.

Costantini, O. (2015). "An informal way to social protection: The case of Eritrean refugees in Rome". In D. J. Narendra Bondla, W. G. C. Smidt, Y. Furusaki, and B. Ayele (eds.) Cultural Landscapes of Ethiopia: Conference Proceedings, Mekelle: Mekelle University Printing Press.

Cresswell, T. (2006). On the Move: Mobility in the Western Modern World, London: Routledge.

Cunningham, H. and Heyman, J. (2004). "Mobilities and enclosures at borders", Identities: Global Studies in Culture and Power, 11 (3): 289-302. https://doi.org/10.1080/10702890490493509

Czaika, M. and de Haas, H. (2014). "Globalization of migration. Has the world become more migratory?", International Migration Review, 48 (2): 283-323. https://doi.org/10.1111/imre.12095

Denaro, C. (2016). "Agency, resistance and (forced) mobilities. The Case of Syrian refugees in transit through Italy", REMHU, Revista Interdisciplinar da Mobilidade Humana, 24 (47). https://doi.org/10.1590/198085852503880004706

Denaro, C. and Vassallo Paleologo, F. (2018). "EU responses to refugees' secondary movements in times of crisis of international protection", In A. Petroff, G. Milios, and M. Pérez (eds.) Refugees on the Move. Political, Legal and Social Challenges in Times of Turmoil, Bellaterra: Universitat Autònoma de Barcelona. Retrieved on January 12, 2019 from: https://ddd.uab.cat/pub/llibres/2018/190846/Focus_Petroff_a2018n5.pdf.

Dykstra, L. J. G., and Van Wissen, P. A. (1999). "Introduction: The life course approach as an interdisciplinary framework for population studies". In L. J. G. Van Wissen and P. A. Dykstra (eds.) Population Issues: An Interdisciplinary Focus, P.A. New York: Kluwer Academic/ Plenum Publishers. https://doi.org/10.1007/978-94-011-4389-9_1

Esses, V. M., Hamilton, L. K. and Gaucher, D. (2017). "The global refugee crisis: Empirical evidence and policy implications for improving public attitudes and facilitating refugee resettlement", Social Issues and Policy Review, 11 (1): 78-123. https://doi.org/10.1111/sipr.12028

Glick Schiller, N. and Salazar, N. B. (2013). "Regimes of mobility across the globe", Journal of Ethnic and Migration Studies, 39 (2): 183-200. https://doi.org/10.1080/1369183X.2013.723253

Gutekunst, M., Hackl, A. and Leoncini, S. (2016). Bounded Mobilities: Ethnographic Perspectives on Social Hierarchies and Global Inequalities, Bielefeld: Transcript Verlag. https://doi.org/10.14361/9783839431238

Lindley, A. and Van Hear, N. (2007). New Europeans on the Move: A Preliminary Review of the Onward Migration of Refugees within the European Union. Centre on Migration, Policy and Society Working Paper 57, University of Oxford. Retrieved on January 12, 2019 from: http://www.compas.ox.ac.uk/wp-content/uploads/WP-2007-057Lindley-VanHear_Onward_Migration_Refugees_EU.pdf

Massey, D. S., Arango, J., Hugo, G., Kouaouci, A., Pellegrino A. and Taylor, J. E. (1993). "Theories of international migration: A review and appraisal", Population and Development Review, 19 (3): 431-466. https://doi.org/10.2307/2938462 
Moraga, J. F., and Rapoport, H. (2014). Tradable Refugee-admission Quotas and EU Asylum Policy. IZA Discussion Paper n. 8683. Bonn: Forschungsinstitut zur Zukunft der Arbeit Institute for the Study of Labor. Retrieved on September 20, 2018 from: http://ftp.iza.org/dp8683.pdf.

Palidda, S. and Martini, F. (2018). "Continuità e mutamenti nelle migrazioni in particolare alla frontiera di Ventimiglia", Altreitalie 56: 117-130.

Poppy, J. and Mayblin, L. (2016). Factors Influencing Asylum Destination Choice: A Review of the Evidence. University of Sheffield working paper: 04/16.1. Retrieved on January 12, 2019 from: https://asylumwelfarework.files.wordpress.com/2015/03/asylum-seeker-pull-factors-working-paper.pdf.

Radjenovic, A. (2017). Secondary Movements of Asylum-seekers in the EU Asylum System. EPRS European Parliamentary Research Service. Retrieved on January 12, 2019 from: http://www.europarl.europa.eu/ RegData/etudes/BRIE/2017/608728/EPRS_BRI(2017)608728_EN.pdf.

Schapendonk, J. (2010). "Staying put in moving sands. The stepwise migration process of Sub-Saharan African migrants heading north". In U. Engel, and P. Nugent (eds.) Respacing Africa, Leiden: Brill.

Schuster, L. (2006). "The continuing mobility of migrants in Italy: Shifting between places and statuses", Journal of Ethnic and Migration Studies, 4: 757-774. https://doi.org/10.1080/13691830500109993

Sirkeci, I. and Cohen, J. (2016). "Cultures of migration and conflict in contemporary human mobility in Turkey”, European Review, 24 (3): 381-396. https://doi.org/10.1017/S1062798716000119

Toma, S. and Castagnone, E. (2015). "What drives onward mobility within Europe? The case of Senegalese migration between France, Italy and Spain", Population, 70 (1): 65-95.

Turner, L. (2017). “Who will resettle single Syrian men?”, Forced Migration Review 54: 29-31. 


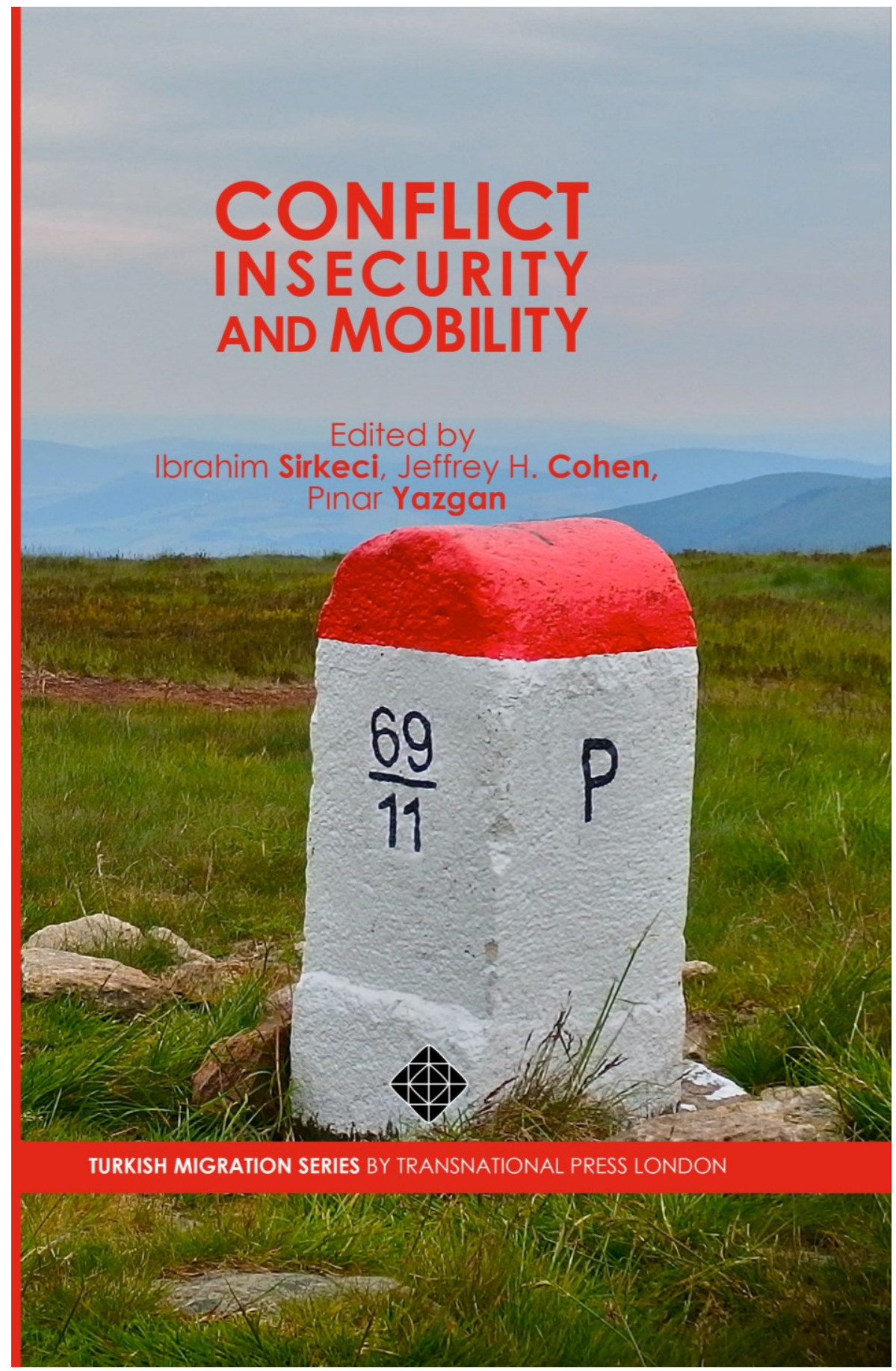

www.tplondon.com 